\title{
千葉県鴨川沿岸の海水細菌
}

\author{
清 水潮・相 磯和 嘉* \\ (1962 年 9 月 10 日受理)
}

\section{OCCURRENCE AND DISTRIBUTION OF HETEROTROPHIC BACTERIA IN SEA WATER FROM THE KAMOGAWA BAY}

\author{
Usio Simpu and Kazuyoshi Aiso
}

An investigation of the bacterial flora of the sea water from the inshore environment of the Kamogawa Bay (Fig. 1) was carried out at the four seasons of 1961.

The bacterial population seemed to decrease in winter and increase in other seasons (Table 2). Some 475 strains of bacteria were isolated by membrane filter method and investigated their morphological and cultural characteristics using test media containing $3 \%$ of $\mathrm{NaCl}$.

For cultures isolated in winter, optimun temperatures for growth were relatively low and the greater part of them failed to grow at $37^{\circ} \mathrm{C}$. (Table 5). Most of them (82\% of the isolates) were sea-water-loving (halophilic) species showing the optimal growth at about $3 \%$ of $\mathrm{NaCl}$ concentration and no visible growth of these isolates was occurred at $\mathrm{NaCl}$ concentration lower than $0.1 \%$. Remaining one fifth of the cultures showed good growth on the media oontaining less than $0.1 \%$ of $\mathrm{NaCl}$ and had no marked optimum growth range for $\mathrm{NaCl}$ concentration.

Distinct differences in the distribution of bacterial genera was observed between halophilic and non-halophilic bacteria, halophilic group was mainly consisted of Pseudomonas, Achromobacter, Vibrio, and Photobacterium, while dominant genera in non-halophilic group were Pseudomonas, Achromobacter, Bacillus and Flavobacterium. (Table 6).

The composition of the bacterial flora analyzed according to the scheme of Fig. 3 was as follows; Vibrio $37.3 \%$, Pseudomonas $29.8 \%$, Achromobacter $21.3 \%$, Aeromonas $0.4 \%$, Photobacterium $0.4 \%$, Flavobacterium 2.1\%, Bacillus $5.5 \%$, Micrococcus $0.4 \%$, Coryneforms (Pseudobacterium) $0.4 \%$ and Miscellaneous 2.3\% (Table 6).

Among the isolated cultures, a species of Vivrio, possessing the charecteristics similar to those of the „pathogenic halophile which was isolated from the patients of a gastroenteric disease", constituted considerable proportions through a year.

海洋微生物の多様な生物学的特性は古くから WAKSMAN ${ }^{1,2)}$, ISACHENKo ${ }^{3)}$ らによつて注目学竌, 研究さ れて数り，その後も备国の学者が数多くの海水細菌の䃘究発表している。それらの中でも，アメリカの

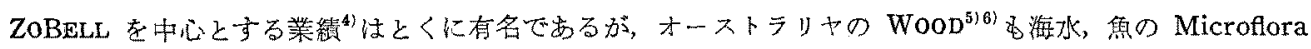

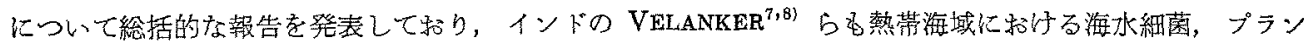

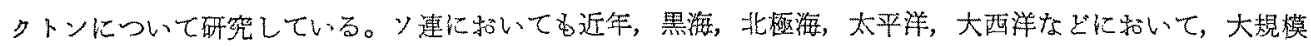

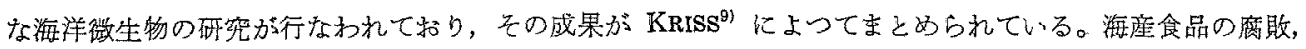
鯘度保持に関連して行なわれた海水，魚の細菌学的研究は，従来カナダ，イギリスでとくに精力的にすすか られて法り，SHEWAN ${ }^{101}, \operatorname{TARR}^{11)}$ の総説当ある。

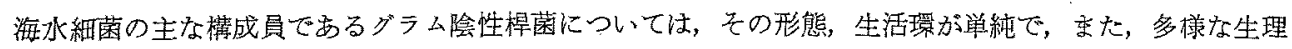
的性質にもかかからず互いに他と区別できる特街的な形筫を有するものが少ない，などの事情のために，従

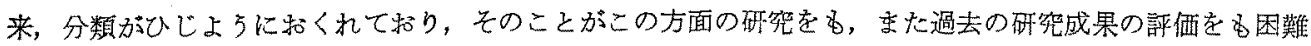

* 千葉大学腐敗研究所 (The Institute of Food Microbiology, Narashino, Chiba, Japan). 
にさせるひとつの理由になつていた。近年ようやく SHEWAN ${ }^{121}$ ， LISTON ${ }^{13\rangle}$ らによつて，グムム陰性棉菌

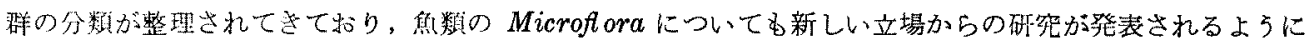
なつた ${ }^{14,15,16) 。}$

わが国に挄いては，従米水産国と称されながらす海水細囷についての包括的な㖄究はほとんど行なわれて

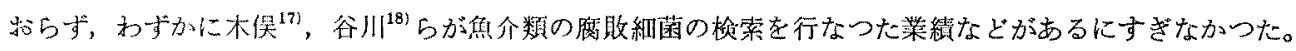

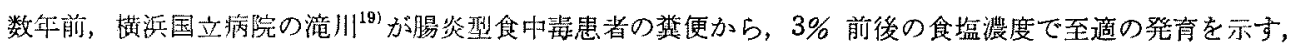

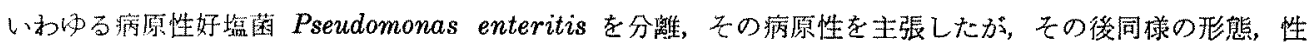
状をもつ菌が食中琵患者からつぎつぎに分離され，さらにこの菌が海水に由来し，近年わが国に多発する生

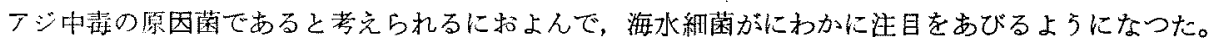

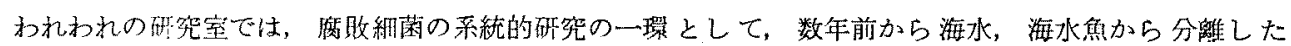
Pseudomonas $^{20,21)}$, Aeromonas ${ }^{221}$,Photobacterium ${ }^{23)}$ なとのグラム陰性桿菌について一速の䃘究をすすか てきたが，今回これらの研究の延长として，千葉県水座試䮖場，牁川保健所のこ㽖力を得て，房総半島鴨川 沼岸の做水細菌の分机について総括的な研究完行なつた。

方
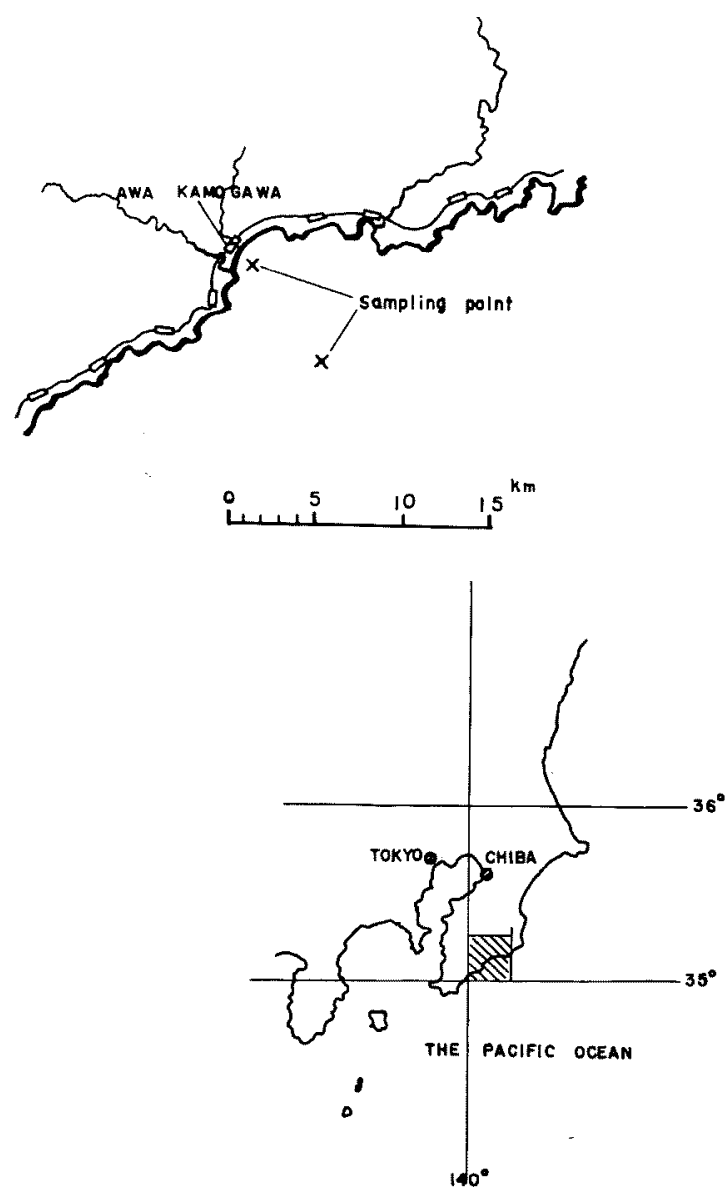

Fig. 1. Sampling station in Kamogawa Bay.
法

採水海水採取は 1961 年 2 月加ら 11 月にか子, 冬 $(2$ 月 16 日), 春 (4月 28 日), 夏 $(7$ 月 22 日), 秋 (11 月 10 日）の 4 時期に 1 回ずつ行なつた。採水 場所はいずれる房総半島鴄川沖の沿岸から 約 $1 \mathrm{~km}, 6 \mathrm{~km}$ の点 (Fig. 1) で, 採水 は城菌 ハイロート採水器 $(500 \mathrm{~m} l$ 特よび $100 \mathrm{ml}$ ) 用いて，表面から $50 \mathrm{~cm}$ の表 層海水, 表面から $15 \mathrm{~m}$ 内外の深さの海水 を，それぞれ同一点で数 $10 \mathrm{~m}$ の間隔を谅 いて 2 回採水乙た。採水点の水深, 採水個 所の水深, 水温などは Table 1 に示した。 採取した海水は滅菌試薬ビンに移し，その 杰亦研究室にもちか克つて実駼に供した。 採水から菌の分離操作開始亲での時間は約 6 时間であつた。

菌株の採集＼cjkstart菌の分離はメンブランフィ ルター法に上つて行なつた。隇菌したメン ブランフィルターCo 5 上に海水 $100 \mathrm{~m} l$, $20 \mathrm{ml}, 5 \mathrm{ml}, 1 \mathrm{ml}$ 招上び隇菌 $3 \%$ 食塩水 で 10 倍に希积した海水 $2 \mathrm{~m} l$ を流し，沪 過後フィルターを寒天平板培地表面に移し て培㟴した。培地は種々检討の結果 Table 2 に示した組成のものを使用した。培養は $20^{\circ} \mathrm{C}$ で行ない，48 時間後に発有集落を計 数し，さらに 100 個内外の集落発育を見た 各採水点ごとのフィルターの一画を任意に 区切つて画内のすべての集落 30 40 個を 釣菌し，直ちた上述の培地を用いて再分離 
Table 1. Data of sampling point.

\begin{tabular}{|c|c|c|c|c|c|}
\hline Date & $\begin{array}{l}\text { Distance } \\
\text { from the } \\
\text { coast } \\
(\mathrm{Km} \text { ) }\end{array}$ & $\begin{array}{l}\text { Depth } \\
\text { to the } \\
\text { bottom } \\
\text { (m.) }\end{array}$ & $\begin{array}{l}\text { Depth of } \\
\text { sampling } \\
\text { point } \\
\text { (m.) }\end{array}$ & $\begin{array}{l}\text { Tempera- } \\
\text { ture of } \\
\text { sea water } \\
\left({ }^{\circ} \mathrm{C} .\right)\end{array}$ & $\begin{array}{c}\text { Salinity } \\
\text { of sea } \\
\text { water } \\
(\%)\end{array}$ \\
\hline \multirow{2}{*}{$\begin{array}{l}16 \text { th, } \\
\text { February }\end{array}$} & 1 & 14 & $\begin{array}{c}0.5 \\
12\end{array}$ & $\begin{array}{l}12.6 \\
12.2\end{array}$ & - \\
\hline & 6 & 105 & $\begin{array}{l}0.5 \\
15\end{array}$ & $\begin{array}{l}14.7 \\
13.3\end{array}$ & - \\
\hline \multirow{2}{*}{$\begin{array}{l}28 \text { th, } \\
\text { April }\end{array}$} & 1 & - & $\begin{array}{l}0.5 \\
10\end{array}$ & $\begin{array}{l}17.9 \\
16.7 \\
\end{array}$ & $\begin{array}{l}33.87 \\
34.41 \\
\end{array}$ \\
\hline & 6 & - & $2^{0.5}$ & $\begin{array}{l}17.1 \\
16.3\end{array}$ & $\begin{array}{l}34.85 \\
34.51\end{array}$ \\
\hline \multirow{2}{*}{$\begin{array}{l}22 \text { nd, } \\
\text { July }\end{array}$} & 1 & 23 & ${ }_{15}^{0.5}$ & $\begin{array}{l}24.5 \\
22.0\end{array}$ & 34.13 \\
\hline & 6 & 120 & $\begin{array}{l}0.5 \\
15 \\
\end{array}$ & $\begin{array}{l}24.5 \\
22.0 \\
\end{array}$ & 34.13 \\
\hline \multirow{2}{*}{$\begin{array}{l}10 \text { th, } \\
\text { October }\end{array}$} & 1 & 17 & ${ }^{0.5}$ & $\begin{array}{l}22.4 \\
22.1\end{array}$ & - \\
\hline & 6 & 108 & $\begin{array}{l}0.5 \\
20\end{array}$ & $\begin{array}{l}22.6 \\
22.4\end{array}$ & - \\
\hline
\end{tabular}

Table 2. Composition of medium used for the isolation.

fish extract $(1 \mathrm{~kg}$, of horse- $\cdots \cdots 1 l$. mackerel was extracted with $2.5 l$ of sea water and $0.5 l$ of tap water)

polypeptone.$\cdots \ldots \ldots \ldots \ldots \ldots \ldots 5 \mathrm{~g}$. meat extract $\ldots \ldots \ldots \ldots \ldots \cdots \cdots, \mathrm{g}$. yeast extract $\ldots \ldots \ldots \ldots \ldots \ldots \ldots, \mathrm{g}$. glucose $\ldots \ldots \ldots \ldots \ldots \ldots \ldots \ldots 1 \mathrm{~g}$.

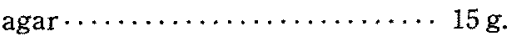
$\mathrm{pH} 7.0$

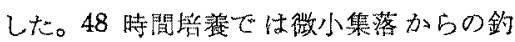
菌は注意して行なわないとかなり四難な゙ が，培盖時間がさらに長くなると大瑟の集

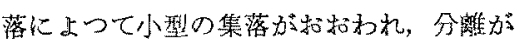
目難になる。フィルター上で swarmingす る菌は，今回の英㯺では少なかつた。

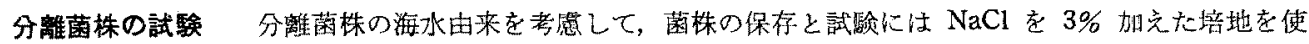
用した。これら菌株の大部分は，すくなくとも分離後しばらくの閻は，ふつらの，0.5\% 程度の $\mathrm{NaCl} の 入$

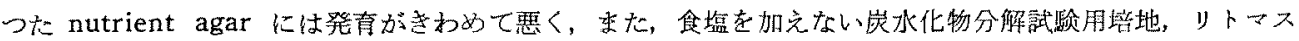
ミルク，グルュース燐酸塩培地，SIM 培地など，大部分の試験用培地にはまつたく発䏍しない。

形態，運動性の㛟查扣上び䩒毛染色には，非好塩性の菌（分離当初から $0.1 \% \mathrm{NaC1}$ 加ポリペプトン水 に発育するもの）にたいしては $3 \% \mathrm{NaCl}$ 加坮地ととるに，ふつ5の nutrient agar 特よび broth る併

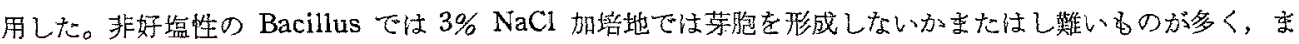

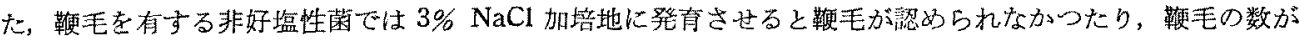
少なく周毛性の鞭毛が極毛性に見楞李られることが多い。鞭毛染色は LEIFSON ${ }^{24)}$ の力法によつた。管光色

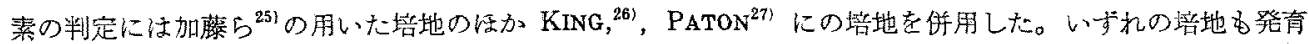

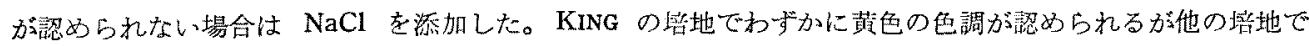
は色素産生が検出できない場合は一沉陰性と判定した。岸长化物分解能の检查に通常の BTB ペプトン水 BARSIEKOW 培地を用いると，菌株によつては，ペプトンからのアンモニけの痤生が強く，糖の分解による 酸の産生が判定できない。われわれは SMTH $5^{281}$ が Bacillus 㕍の梌索に用いた半合成培地に $3 \% \mathrm{NaCl}$

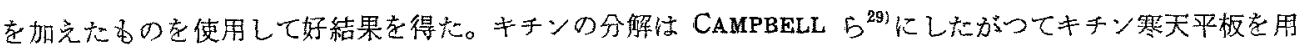

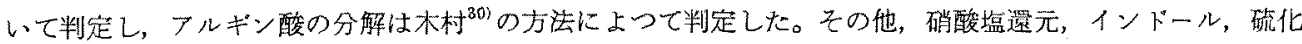
水素の産生，ゼラチン液化，でんぶん水解，リトマスミルクの变化などの性状試験はそれぞれ $3 \% \mathrm{NaCl}$

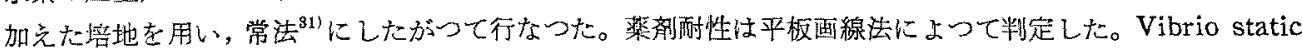
agent 0/129 (2, 4-diamino-6, 7-diisopropylpteridine) にたいする感受性は，0/129を，めの5乳銶で微粉

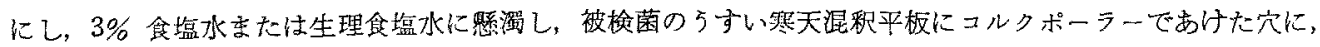

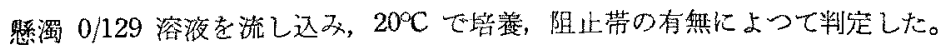

\section{結}

\section{果}

発热集落数 メンブランフィルタ一上に発育した集落数を海水 $1 \mathrm{ml}$ 当りの数に換算して示すと Table 3 のようになる。表にみられるように冬季には他の時期に比べて集落数がいちしるてく少ない。

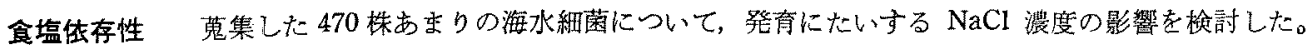
正確に $0,0.1,0.2,0.5,1,3,5,7,10,13 \%$ の $\mathrm{NaCl}$ を含し水 $1 l$ にポリ゚プトン $10 \mathrm{~g}$, 粉末寒天 
Table 3. Colony numbers on membrane filter incubated $48 \mathrm{hrs}$, at $20^{\circ} \mathrm{C}$. (calculated at numbers per $1 \mathrm{ml}$ of sea water)

\begin{tabular}{|c|c|c|c|c|}
\hline $\begin{array}{l}\text { Date of } \\
\text { isolation }\end{array}$ & $\begin{array}{l}\text { Distance } \\
\text { from the } \\
\text { coast } \\
(\mathrm{Km})\end{array}$ & $\begin{array}{l}\text { Depth cf } \\
\text { sampling } \\
\text { point } \\
\text { (m) }\end{array}$ & $\begin{array}{l}\text { Numbe } \\
\text { colony p } \\
\text { of sea }\end{array}$ & $\begin{array}{l}\text { pers of } 1 \mathrm{ml} \\
\text { water }\end{array}$ \\
\hline \multirow{2}{*}{$\begin{array}{l}16 \text { th, } \\
\text { Feb. }\end{array}$} & 1 & $1^{0.5}$ & $\begin{array}{c}8.2 \\
14.2\end{array}$ & $\begin{array}{r}9.2 \\
16.3\end{array}$ \\
\hline & 6 & $\begin{array}{l}0.5 \\
15\end{array}$ & $\begin{array}{l}3.0 \\
2.5\end{array}$ & $\begin{array}{l}3.5 \\
2.7\end{array}$ \\
\hline \multirow{2}{*}{$\begin{array}{l}28 \text { th, } \\
\text { Apr. }\end{array}$} & 1 & $\begin{array}{l}0.5 \\
10\end{array}$ & 39,320 & 81 \\
\hline & 6 & $\begin{array}{l}0.5 \\
20\end{array}$ & $\begin{array}{l}60 \\
71\end{array}$ & $\begin{array}{r}96 \\
320 \\
\end{array}$ \\
\hline \multirow{2}{*}{$\begin{array}{l}22 \text { nd, } \\
\text { Jul. }\end{array}$} & 1 & $\begin{array}{l}0.5 \\
15\end{array}$ & $\begin{array}{l}178 \\
172 \\
\end{array}$ & $\begin{array}{l}230 \\
500\end{array}$ \\
\hline & 6 & $\begin{array}{l}0.5 \\
15\end{array}$ & $\begin{array}{r}46 \\
126 \\
\end{array}$ & $\begin{array}{l}103 \\
148\end{array}$ \\
\hline \multirow{2}{*}{$\begin{array}{l}10 \text { th, } \\
\text { Oct. }\end{array}$} & 1 & $\begin{array}{l}0.5 \\
15\end{array}$ & $\begin{array}{l}43 \\
32\end{array}$ & $\begin{array}{l}51 \\
52 \\
\end{array}$ \\
\hline & 6 & 20 & $41, \quad 20$ & 107 \\
\hline
\end{tabular}

Table 4. Distribution of sea-water-loving bacteria

\begin{tabular}{|c|c|c|c|}
\hline \multirow[b]{2}{*}{$\begin{array}{l}\text { Date of } \\
\text { isolation }\end{array}$} & \multirow{2}{*}{$\begin{array}{l}\text { Distance } \\
\text { of } \\
\text { sampling } \\
\text { station } \\
(\mathrm{Km})\end{array}$} & \multicolumn{2}{|c|}{ Numbers of bacteria } \\
\hline & & $\begin{array}{c}\text { Sea-water-* } \\
\text { loving } \\
\text { bacteria }\end{array}$ & $\begin{array}{c}\text { Non-sea-** } \\
\text { water-loving } \\
\text { bacteria }\end{array}$ \\
\hline 16 th, Feb. & $\begin{array}{l}1 \\
6\end{array}$ & $\begin{array}{l}48 \\
60\end{array}$ & $\begin{array}{r}10 \\
2\end{array}$ \\
\hline 28 th, Apr. & $\begin{array}{l}1 \\
6\end{array}$ & $\begin{array}{l}36 \\
52\end{array}$ & $\begin{array}{l}25 \\
17\end{array}$ \\
\hline 22 nd, Jul. & $\frac{1}{6}$ & $\begin{array}{l}48 \\
60\end{array}$ & $\begin{array}{l}6 \\
4\end{array}$ \\
\hline 10 th, Oc & $\begin{array}{l}1 \\
6\end{array}$ & $\begin{array}{l}42 \\
44\end{array}$ & $\begin{array}{r}13 \\
8\end{array}$ \\
\hline
\end{tabular}

* Bacteria not grown on the media containing less than $0.1 \% \mathrm{NaCl}$, and having the optimum $\mathrm{NaCl}$ concentration between 1 and $5 \%$.

** Bacteria grown on the media containing less than $0.1 \% \mathrm{NaCl}$.

$15 \mathrm{~g}$ 索加党た培站平板に，菌の $3 \% \mathrm{Na}$ $\mathrm{Cl}$ 加 broth 24 時閪培盖老白金耳で画 楾染坤し， $20^{\circ} \mathrm{C}$ に培盖，3日（72 時間） 物よび7日後に判定した。 $5 ， 7,10 \%$ $\mathrm{NaCl}$ 濃度のbのについては7日目に発 育した子のる隰性とし，その他の濃度の 娄のについては 3 日目判定の結果を採つ た。各塩灌度に括いて発育する株数の割 合を Fig. 2 に示した。おれわれの分離 した海水細菌の大部分は $0 \sim 0.1 \% \mathrm{NaCl}$ 加パプトン寒天に発充しないが、これら はすベて $3 \% \mathrm{NaCl}$ 付近に至適の発育を 示した。少数の, $0 \sim 0.1 \% \mathrm{NaCl}$ 澧度て 発育す西菌株はその大部分が $0.1 \sim 0.5$

濃度で至適の発育を示し，それょり程濃度が高くなるにしたがつて発育が弱くなる。この結果から，分離さ

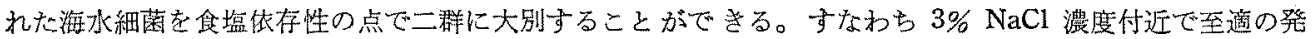
育を示す好塩性（好海水性）の群と，0 0.1\% NaCl 浱度で良く発育する非好塩性の細菌群とである。好塩 性菌と非好塩性菌の割合を Table 4 に示した。好塩性組菌の大部分は $0.5 \sim 1 \%$ か 5 5 7\%の塩濃度の 範国に発育する当ので，これが冬李分離株の $82.3 \%$ ，春季分離株の $70.4 \%$ ，夏季分湤株の $53.7 \%$ ，秋季 分離株の $71.5 \%$ 莫めた。

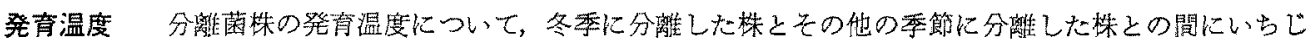

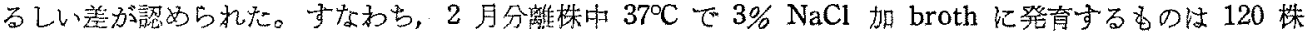

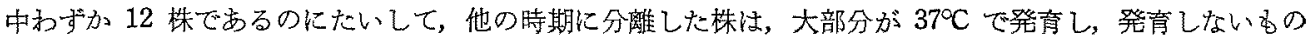
は4 月分離株中 7 株，7 月分離株中 1 株，11月分離株中 3 株で，きかるて少なかつた。

分離株を备季節ごとに形態，性状にしたがつて区分し，各区分から 1〜数株ずつ，合計 194 株を壳らび， 


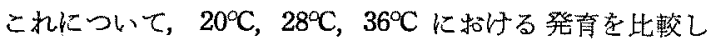

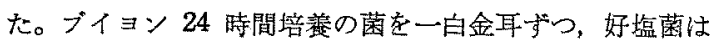
$3 \% \mathrm{NaCl}$ 加 broth $儿$, 非好塩菌仗ふつうの broth 亿接 璉し，それぞれの温度の粰卵器に培堹し，18 時間後に濁 可強さを肉腿で判定した。結果を $20^{\circ} \mathrm{C}, 28^{\circ} \mathrm{C}, 36^{\circ} \mathrm{C} て ゙$ 至道の発育を示す可の, $10 \sim 28^{\circ} \mathrm{C}, 28 \sim 36^{\circ} \mathrm{C}, 20 \sim 36^{\circ} \mathrm{C}$ の 間で同等の発育を示するのに分けて Table 5 に示した。 冬季比比較的低温で至適の発育を示すものが多く，水温 の上界に伴なつて高温で発育の良いるのが多くなつてゆく 様子がうかがわれる。

分類種々桱討の結果，分離菌を形態，グラム染色性，色素産生，発光，Hugh-Leifson 培地 ${ }^{322}$ にる

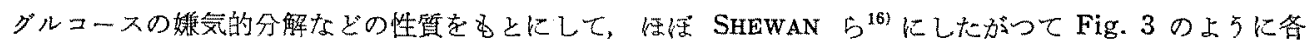
Genusに分けた。

分離菌株を好塩性菌，非好塩性菌の扮の特のについて，この図式にしたがつて分類すると Table 6 の上 らになる。Vibrio については，でんぷん水解，ゼラチン液化，硝酸塩䢬元の性状をつすの病原性好 塩菌類似株として，别に一括して示した。主た Achromobacter，Flavobacterium については，堆毛性の 鞭毛を有するるのを一括した。Table 6 から見られるように，分離株中グラム陽性菌はわずかで，大部分は グラム陰性桿菌である。グラム陰性桿菌のうらでは Pseudomonas, Achromobacter とならんで, とくに Vibrio の割合が大きいことが注目され，そのうちでも病原性好塩菌類似株が四季を通じて高い率を占好て いる。Enterobacteriaceae に属すると思われるるのはすつたく見出庀なからた。

グラム陽性細菌 グラム陽性細菌 30 株のうち，26 株までが Bacillus で，Micrococcus 注 2 株， また

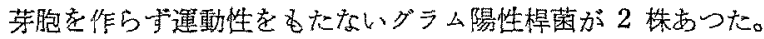

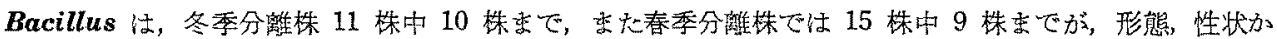

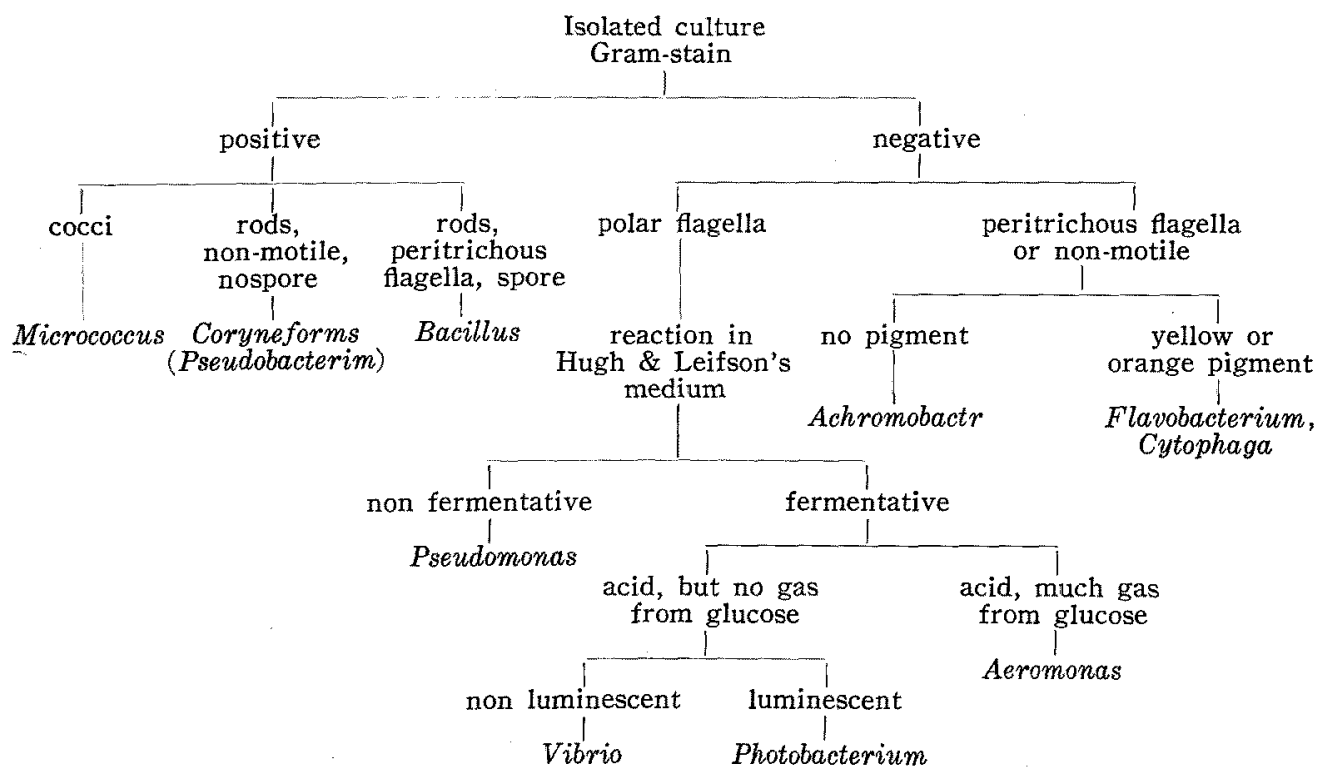

Fig. 3. A scheme for the identification of genera of cultures isolated from sea-water.
Table 5. Numbers of strains which showed optimal growth at given temperature or temperature range

\begin{tabular}{|c|c|c|c|c|c|c|}
\hline \multirow{2}{*}{$\begin{array}{l}\text { Date of } \\
\text { isolation }\end{array}$} & \multicolumn{6}{|c|}{ Temperature } \\
\hline & $20^{\circ}$ & $\begin{array}{r}20 \sim \\
28^{\circ}\end{array}$ & $28^{\circ}$ & $\begin{array}{r}28 \\
36^{\circ}\end{array}$ & $36^{\circ}$ & $\begin{array}{r}20 \sim \\
36^{\circ} \\
\end{array}$ \\
\hline 16 th, Feb. & 16 & 5 & 10 & 0 & 0 & 0 \\
\hline 28 th, Apr. & 19 & 13 & 17 & 2 & 10 & 6 \\
\hline 22 nd, Jul. & 2 & 3 & 16 & 9 & 14 & 2 \\
\hline 10 th, Oct. & 7 & 2 & 18 & 9 & 8 & 6 \\
\hline
\end{tabular}


Table 6. Distribution of organisms isolated from sea-water

\begin{tabular}{|c|c|c|c|c|c|c|c|c|}
\hline \multirow{2}{*}{$\begin{array}{c}\text { Genus and/or kind } \\
\text { of bacteria }\end{array}$} & \multicolumn{8}{|c|}{ Numbers of various bacteria Date of isolation } \\
\hline & $\begin{array}{l}16 \text { th, } \\
\text { SL* }\end{array}$ & 'Feb. & $\begin{array}{l}28 \text { th } \\
\text { SL* }\end{array}$ & $\begin{array}{l}\text { Apr. } \\
\text { NSL** }\end{array}$ & $\frac{22 \mathrm{nc}}{\mathrm{SL} *}$ & d, Jul. & $\frac{10 \text { th }}{\mathrm{SL} *}$ & NSL** \\
\hline \multicolumn{9}{|l|}{ Vibrio } \\
\hline Pathogenic haloplile group*** & 26 & 0 & 33 & 0 & 45 & ${ }^{2} 0$ & 30 & 0 \\
\hline Other Vibrios & 17 & 0 & 7 & 0 & 9 & 0 & 10 & 0 \\
\hline Photobacterizim & 1 & 0 & 0 & 0 & 0 & 0 & 1 & 0 \\
\hline Aeromonas & 1 & 0 & 0 & 1 & 0 & 0 & 0 & 0 \\
\hline \multicolumn{9}{|l|}{ Pseudomonas } \\
\hline nonfluorescent & 5 & 0 & 47 & 8 & 47 & 1 & 23 & 9 \\
\hline fluorescent & 0 & 0 & 0 & 2 & 0 & 0 & 0 & 0 \\
\hline \multicolumn{9}{|l|}{ Achromobacter } \\
\hline non-motile & 43 & 2 & 4 & 3 & 7 & 1 & 23 & 6 \\
\hline motile & 5 & 0 & 0 & 1 & 0 & 2 & 4 & 0 \\
\hline Flavobacterium & 0 & 0 & 0 & 4 & 0 & 5 & 0 & 0 \\
\hline Bacillus & 0 & 11 & 0 & 15 & 0 & 0 & 0 & 0 \\
\hline Micrococcus & 0 & 0 & 0 & 1 & 0 & 0 & 1 & 0 \\
\hline Coryneforms & 2 & 0 & 0 & 0 & 0 & 0 & 0 & 0 \\
\hline Unidentified & 6 & 1 & 0 & 4 & 0 & 0 & 0 & 0 \\
\hline Total & 106 & 14 & 91 & 39 & 108 & 10 & 92 & 15 \\
\hline
\end{tabular}

* Sea-water-loving bacteria not grown on the media containing less than $0.1 \% \mathrm{NaCl}$.

** Bacteria grown on the media containing no salt.

*** Vibrios having the same biochemical characteristics as "pathogenic halophile".

与 B. megaterium に一致した。これら megaterium の大部分は，とくに $3 \% \mathrm{NaCl}$ 加培地で鿓色の菌 体色素を産生し，また $3 \% \mathrm{NaCl}$ 加堷地では，芽胞形成白连動性も認められないものが多からた。

分離されたグラム陽性囷は大部分（30 株中 27 株）が非好塩性菌であつた。

グラム除性細菌グラム陰性桿菌中，少数の Flavobacterium，2 株の Ps.aeruginosaを際いて明陧な

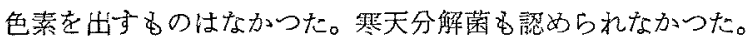

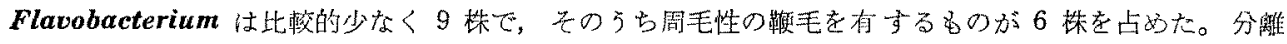
Flavobacterium はい寸れわ非好塩性であつた。

Achromobacter は分離株中 6\%（春分離秼）加 42\% (冬分離株) 古占心た。総数 100 株の5ち87\% が非運動性の菌でり，また $84 \%$ が好塩性菌であった。分離した Achromobacter の一般的な性状は Table 7 に示した。この属の細菌は Pseudomonas, Vibrio に比べて発育の弱い子のが多く, 中には nutrient agarにイーストエキスを加党なければ発育しなくなる早のもあつた。

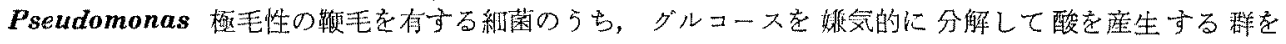
Vibrio, Aeromonas, Photobacterium のいずれかに含め, 残りを Pseudomonas とした。冬季分漓侏中

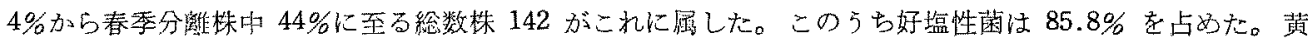

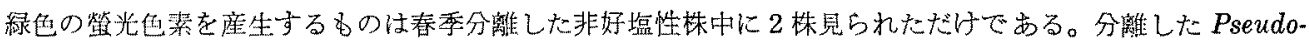
manas の性状は Table 7 に示した。これら菌株中 20 株あまりを兄らんて Vibrio static agentにたいす

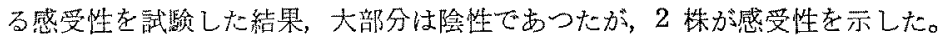

Photobacterium, Aeromonas はと西に少なく，2 株つしか見られなからた。Photobacterium は 2 株と为好塩性で, Vibrio static agent に感受性を有し志。Aeromonas は 2 秼中 1 株が非好塩性菌で， 
Table 7. Characteristics of isolated cultures.

\begin{tabular}{|c|c|c|c|c|c|c|c|c|c|c|c|}
\hline & 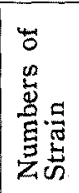 & 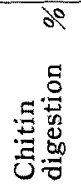 & de & 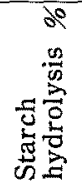 & 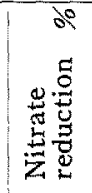 & a & 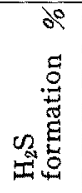 & 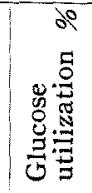 & 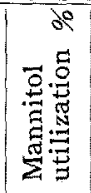 & 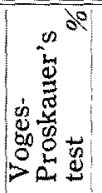 & $\begin{array}{c}\text { Sensitivity } \\
\text { for } \\
\text { Penicillin } \\
20 \text { I. U. }\end{array}$ \\
\hline Vibrio & 177 & 64.7 & 93.4 & 81.0 & 87.7 & 77.3 & 46.0 & 98.5 & 93.9 & 6.2 & 2.3 \\
\hline Aeromonas & 2 & 0 & 50 & 0 & 100 & 0 & 0 & 100 & 50 & 100 & 0 \\
\hline Photobacterium & 2 & 50 & 50 & 0 & 100 & 0 & 0 & 100 & 50 & 0 & 0 \\
\hline Pseudomonas & 142 & 2.8 & 75.0 & 38.8 & 22.9 & 3.5 & 2.1 & 79.8 & 22.9 & 2.1 & 9.9 \\
\hline Achromobacter & 101 & 2.0 & 42.4 & 19.8 & 15.8 & 2.0 & 0 & 85.2 & 58.3 & 35.6 & 39.6 \\
\hline Flavobacterium & 10 & 0 & 80 & 20 & 60 & 0 & 0 & 80 & 80 & 40 & 60 \\
\hline Bacillus & 26 & 0 & 100 & 73.0 & 7.7 & 0 & 0 & 100 & 100 & 3.7 & 96.0 \\
\hline Micrococcus & 2 & 0 & 50 & 0 & 100 & 0 & 0 & 0 & 0 & 0 & 100 \\
\hline Coryneforms & 2 & 0 & 50 & 50 & 100 & 0 & 0 & 100 & 50 & 0 & 0 \\
\hline Miscellaneous & 11 & 0 & 0 & 0 & 54.5 & 0 & 0 & 100 & 0 & 54.5 & 27.2 \\
\hline Total & 475 & 25.7 & 74.7 & 50.9 & 47.7 & 31.7 & 17.9 & 89.9 & 62.3 & 13.5 & 21.7 \\
\hline
\end{tabular}

2 株とも Vibrio static agent に感受性を示さなからた。

Vibrio 分離株中極毛性の鞭毛を有するPseudomonad で踭気的に精を分解するが，ガスは産生しない群 が，つねにかなり高率 (31〜46\%) に存在した。これ5の5ち性状の異なる株の代表 20 株あまりについて Vibrio-static agent にたいする感受性を試路したところ、いずれも感受性を示した。これら菌株中, 明屪 に弯曲した形熊を示するのは比較的少ないが，われわれは SHEWAN ら ${ }^{16}$ にしたがつてこれらをVibrio

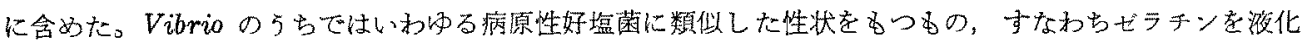

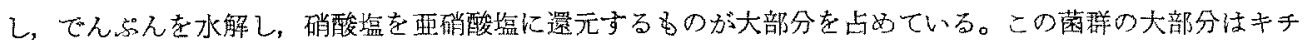
ン分解，インドール産生，リトマスミルク消化，マンニット分解の性犋をもつているが，このうち一つまた

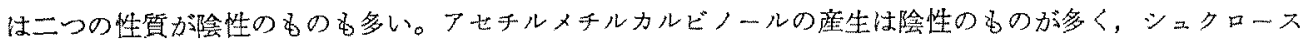
分解能湯性のものが多い。冬李採取株は，他の性状では一致するが，すくなくとも分離当初には大部分が $37^{\circ} \mathrm{C}$ で発育しない。

\section{考察}

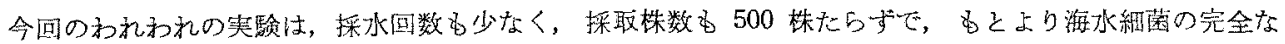

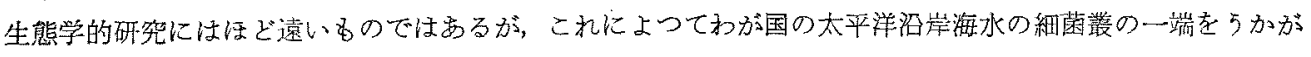
うことはできるであら5。

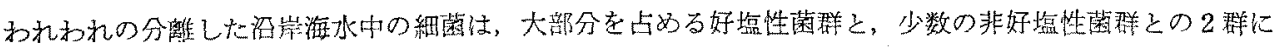

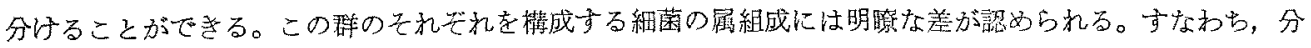
離菌中 Bacillus, Micrococcus, Flavobacterium はすべて非好塩性細菌に属乙, 一方, Photobacterium, Vibrio はすべて好塩性維菌である。Pseudomonas, Achromobacter は好塩性のるのが数の上からは多から

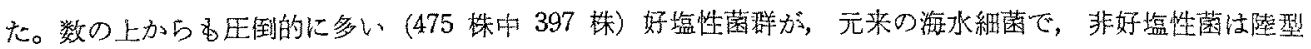

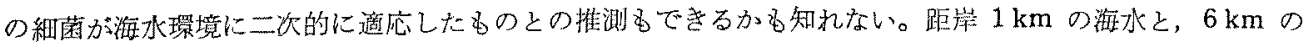
海水をでは，非好塩性菌数の敖合にかなりの差が認められた。

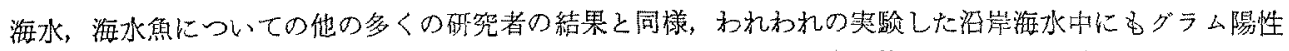

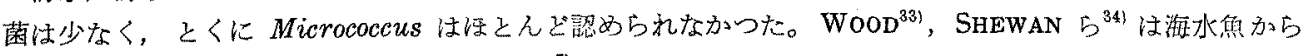
Corynebacterium 老分離して郝り KRISS ら 


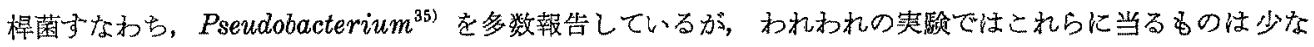

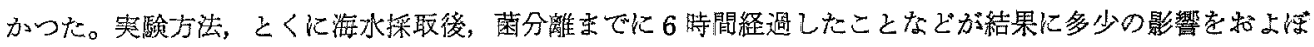
しているか子智虬ない。木村 ${ }^{361}$ 注海水採取後時間とともにグラム陽性菌の割合が隇少すると述べている。木

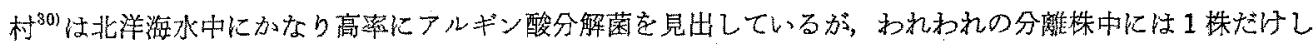
か見出されなからた。地域により盖があるものと思われる。

グラム陰性悍菌中，極毛性の鞭毛党有するるの以外の色素非産生株をすべて Achromobacter とした。こ の中に注，リトマスミルクを明膫に青変するが，糖の分解力のかなり強いるのが多数存在する。したがつて， Bergey's manual にしたがつて Achromobacter とAlcaligenes を区別することは区つて混乱を招くと思 われる。

Vibrio 々 Aeromonas, Photobacterium 三者の間には密接な類粶関係が存在するように思われ，これら の分類には，さらに検討さるべき問題が残されている。Vibrioのうちでは，病原性を別にすれば，形態，生

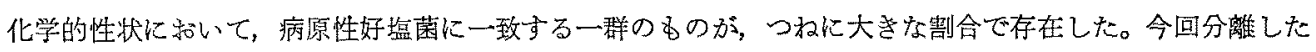
これら病原性好壏菌類似株は, 大部分 Voges-Proskauer 反応陰性で, また寒天培地上で swarming する ものはなからたが，海水，海水魚からは，とくに增菌培地を使用して菌を分離する際，寒天培地上で特徽的 な swarming をし，アセチルメチカルビノールを産生するすのが多量住分離でさる。これらについてはす でに富平 ${ }^{20}$ がくかしく報告しているが，これら两群の病原性好塩菌類似株は，人から分離された病原性好塩

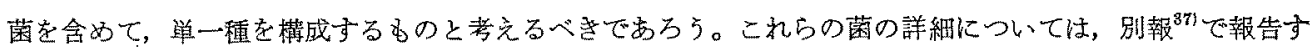
るが，これら病原甠好塩菌類似株が，沿岸海水中につねに高率に見出されることは，これらの菌が，重肉中 で速やかな增殖を行ならことと考克合せて，食品筒生，食品保蔵の面で大きな意味をすつと考党られる。

終りに，赛験を手伝つて下さつた辰巳和世さん，沢田文枝さんに心からの感謝の意を表します。

要約

1. 1961 年の四季にわたつて，房総半島鴫川沿岸の海水中の有機栄盖細菌孛分離し，その分布ならびに 性状赽矿然した。

2. 海水中の細菌数は冬季に少なく，他の三つの季節に多い傾向が認められた。冬季に分離した細菌の大 部分は $37^{\circ} \mathrm{C}$ で発育しない。発育の至適湿度も一般に冬季分離株では低く，夏季分離株では高い。

3. 分離細菌の $84 \%$ は好塩性細菌で 0.1\% 以下の食塩瀑度のペプトン寒天上に発育はず， $3 \%$ 付近に 至適食盐浱度を有した。残りの $16 \%$ の細菌は $0.1 \sim 0.5 \%$ 食塩濃度で最高の発育を示し, 塩湛度が高くな るにしたがつて次第に発育が弱季る。非好塩性細菌数の割合は, 沿岸から $6 \mathrm{~km} の$ 海水中では $1 \mathrm{~km}$ の海 水中より常に少ない。

4. 好塸性細菌と非好塩性細菌の属組成の間には美が認められた。すなわら, 分離菌中のVibrio, Photobacterium はす心゙て好壏性細菌であり，一方，Bacillus，Flavobacterium は卞べて非好塩性であつた。

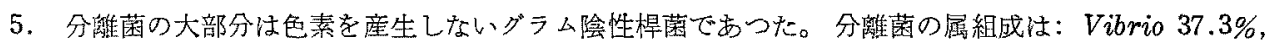
Pseudomonas 29.8\%, Achromobacter 21.2\%, Bacillus 5.5\%, Flavobacterium 2.1\%, Photobacterium, Aeromonas, Micrococcus, Coryneforms がそれぞれ 0.4\%，不明 2.3\%であつた。

6. アルギン酸を分解する菌は活とえど見られず，寒天分解菌は認められなかつたが，キチン分解菌は $26 \%$ に達した。

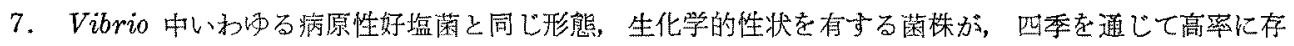
在した。

文献

1) WaKsman, S.A.: Ecol. Monographs, 4, 523(1934).

2) Waksman, S. A., Reuszer, H. W., Carey, C.L., Hotchiss, M. \& RenN, C.E.: Biol. Bull. 64, 183 (1933). 
3) Исаченко, Б.: “Тр. Мурманск. научно-промысловой эксппедйции 1906 года." Петротрад, (1914).

4) ZoBelL, C.E.: Marine Microbiology, Chronica Botanica Co., (1946).

5) Wood, E.J.: Indo-Pacific Fisheries Council Proc. sect. I, III, 69 (1951).

6) Wood, E.J.F.: Aust. J. Mar. Freshw. Res. 4, 160 (1953).

7) Velanker, N.K.: Proc. Indian Acad. Scie. 32, 80 (1950).

8) Velanker, N.K. :Indian J. Fisheries, 2, 96 (1955).

9) Kрисс, А.Е.: “Морская Микробиология (губоководная)" Москва (1959).

10) SHewan, J. M.: J. R. Sanit. Inst., 59, 394 (1949).

11) TARR, H.L.A.: Bacteriol. Rev. 18, I (1954).

12) SHEWAN, J.M., HOBBS, G. \& Hodgkiss, W.: J. appl. Bacteriol., 23, 379 (1960).

13) Colwel, R. R. \& Liston, J.: J. Bacteriol., 82, 1 (1961).

14) Liston, J.: J. gen. Microbiol., 16, 205 (1957).

15) GeoRgala, D.L.: J. gen. Microbiol., 18, 84 (1958).

16) ShewaN, J. M., HobBs, G. \& HodGisiss, W.: J. appl. Bacteriol., 23, 463 (1960).

17) 木俣正夫：食品鹰敗学, 河出書房 (1943).

18）谷川英一・坂井 稳：水産微生物学, 恒星社厚生閣 (1960).

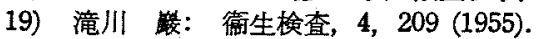

20) 富平輝夫：日本衛生学雑誌, 15, 165 (1960).

21）斎藤英夫：日本徨生学雑誌，15，52 (1960).

22) 海瀬好和：千葉医学会雜誌，36, 148 (1960).

23）飯田宏美：日本傕生学雑誌，15, 103 (1960).

24) Leifson, E.: Atlas of Bacterial Flagellation, p. 1, Academic Press (1960).

25) 加藤 博・宇多謙一・相磯和嘉：千葉大腐研報，12，16 (1954).

26) KING, E. N., WARD, M. K. \& RaneY, D. E.: J. Labor. \& Clin. Medic., 44, 301 (1954).

27) Paton, A.M.: Nature, Lond., 184, 1254 (1959).

28) Smith, N.R., Gondon, R.E. \& Clark, F. E.: Aerobic Sporeforming Bacteria, p. 42, Agric. Monog. No. 16, United States Department of Agriculture, (1952).

29) Campbell, L. L. IUn. \& Williams, O.B.: J. gen. Microbiol. 5, 894 (1951).

30) 木村喬久: 北大水産叠報, 5, 894 (1951).

31) SOCIETY OF AMERICAN BACTERIOLOGIST: Manual of Methods for Pure Culture Study of Bacteria, (1952).

32) HUGH, R. \& LEIFSON, E.: J. Bacteriol., 66, 24 (1953).

33) Wood, E.J.F.: J. gen. Microbiol., 6, 205 (1952).

34) ShewaN, J.M. \& Hodgkiss, W.: Proc. Soc. appl. Bacteriol., 14, vii, (1952).

35) Красильников, Н. А.: Определитель бактерий и актиномицетов, Москва-Ленинград (1952).

36) 木村喬久：私信.

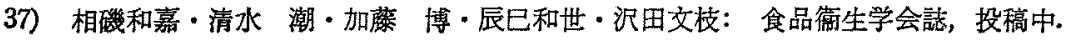

